\title{
The Role of Management Competency in Moderating Organizational Cultural Relations to LPD Performance in Bali Province
}

\author{
Ni Putu Rediatni Giri ${ }^{1}$, Ketut Sudarmini ${ }^{2}$, Nengah Ganawati ${ }^{3}$ \\ 1,2,3 Department of Management, Faculty of Economic and Business, Warmadewa University, Denpasar-Bali, \\ Indonesia
}

Corresponding Author: Nengah Ganawati

\begin{abstract}
This study examines the role of management competence in moderating the relationship between organizational culture and LPD performance. It is hoped that with this model, LPD can optimize everything related to organizational culture and management competence so that it can have positive implications for improving organizational performance. The population of this research is LPD registered and still active in Denpasar City and Badung Regency. The sampling method in this study used the saturated sampling method with a total of 157 samples. This study uses the Structural Equation Modeling (SEM) analysis tool with the SmartPLS version 3.2.9 program used to test the hypothesis.
\end{abstract}

Keywords: Organizational Culture, Management Competence, Organizational Performance

\section{INTRODUCTION}

The Village Credit Institution (LPD) is an institution established specifically for the benefit of the welfare of the Pakraman village community, in its activities it only serves and protects the Pakraman village community. LPD has an important role in serving the residents of Pakraman Village, including small, micro and household businesses in Pakraman Village, which meet the expectations of customers, namely simple procedures, fast processes, and proximity to locations. In addition, the reality is that in saving and providing credit, it is not only given to the community where the LPD operates, but it is also distributed in other Pakraman villages. LPD continues to be developed into a strong and healthy financial institution belonging to Pakraman Village. However, not all LPDs have healthy financial performance. As with the problematic LPD case that occurred in Tabanan Regency. Of the 307 existing LPDs, 60 of them were declared sick. LPD which has been experiencing problems due to mismanagement of funds. The management of these funds, for example, provides loans to customers outside the village of Perkraman, provides loans without collateral and adds to the weakness of human resources (HR) as LPD managers. The phenomenon of LPD performance which is still low, can be seen in the many cases that have ensnared LPD administrators, both corruption cases and other fraud cases in various regions in Bali.

In today's increasingly competitive conditions, to realize organizational performance there are several factors that must be considered and known by academics and practitioners. One of the factors that influence organizational performance is organizational culture (Soedjono, 2005) and (Brahmasari and Suprayetno, 2008). The current organizational culture is the result of various situations related to various organizational problems, one of which is LPD. With the phenomenon of the LPD management scandal and the financial performance that 
befell the LPD organization, this is a sign or signal that the organizational culture in the LPD is allegedly still low. Considering LPD as a financial institution based on local wisdom, namely Balinese culture based on Tri Hita Karana.

Good performance is an organizational goal to be achieved. In general, LPD performance has not been maximized. This is indicated by the presence of several LPDs, whose performance is included in the less healthy category. LPDs really need to have high performance, because LPDs are community financial institutions that exist in rural areas to meet the funding needs of rural communities. If the LPD's performance is good, this will increase the economic development of the community. Likewise, if the performance of the LPD is low, the economic development of the community will also be lower. From the business actor's perspective, in this case the LPD is closely related to the individual performance of the business manager itself.

Several studies related to the relationship of organizational culture to organizational performance were carried out by Ozzie and Malelak (2015). Ozzie and Malelak (2015) examined the relationship between corporate culture and organizational commitment to financial performance in financial companies in Surabaya. The results of the study prove that by applying organizational culture can improve the company's financial performance. The various effects of changes that occur as a result of reforms require organizations, both private and government organizations to carry out innovations to face the demands of change and seek to formulate policies that are in line with environmental changes.

The relationship between organizational culture and employee performance is also found in research conducted by Koesmono (2005) which states that organizational culture has a positive influence on employee performance. The results of research by
Schein (2009), Adriaeni and Gustomo (2012) and Alharbi and Alyahya (2013) show a significant relationship between organizational culture and employee performance that can help improve organizational outcomes. However, the results of research on the relationship between organizational culture and employee performance do not always have a positive effect on employee performance. Giberson et.al (2009) proved that organizational culture is negatively related to leadership. This finding is also supported by Maabuat (2016).

There are still variations in research findings as a research gap, motivating this research. The inconsistency of research results is thought to be influenced by management competence. In this study, management competence is a moderating variable because organizational culture is an active and living phenomenon where the key to an organization is management competence that shapes and influences organizational culture, how to make decisions, management styles and behavioral models in organizations (Morgan, 1997). Leaders also play a central role in shaping and controlling organizational culture (Schein, 1992). Although founders had an early role in building organizational culture, culture has been known to change in the later hands of management (Davis, 1985).

In order to develop SMEs, they should pay attention to the managerial competence involved in running their businesses so that LPD as part of SMEs can exist and be able to compete better both nationally and globally. This finding is also supported by Winarno and Yoga (2015) and Baba (2014). That employee performance is influenced by employee competence will have an impact on organizational performance. The view of the importance of the role of the factors mentioned above motivates researchers to focus this research. The factors that are considered to affect the organizational performance of LPD are 
organizational culture and management competence as moderating variables.

\section{LITERATURE REVIEW RBV Theory}

This study uses RBV theory as a basis to explain the dynamics of organizational performance. Barney (1991) defines that the Resource Based View Theory (RBV) is a framework that emphasizes understanding the sources of sustainable competitive advantage in the company. Barney (1991) explains that resources are a set of factors that are known to be controlled by a company consisting of tangible and intangible assets. One of the intangible assets is intellectual capital, which consists of 1) Human Capital which includes competence, experience and education level. 2) Structural Capital includes Organizational Culture, Organizational Structure and Good Corporate Governance. 3) Capital relations include relationships with customers outside the company.

Resource Based View Theory explain how companies can manage and utilize their resources to achieve competitive advantage and improve the performance of a company. In improving performance, companies must manage and utilize intellectual capital, by implementing Organizational Culture, Management Competence.

\section{The Influence of Organizational Culture on Organizational Performance}

Schein (1992) defines organizational culture as the basic pattern of assumptions found, created or developed by a particular group so that the organization learns to deal with and overcome problems that occur due to external adaptation and internal integration that has been running. Organizational culture is a value system shared by members of an organization that distinguishes the organization from other organizations. Organizational performance (LPD) is a work achievement and the process of implementing organizational goals to be achieved. Performance or work performance can be measured through certain measurements, this study uses the Balanced Scorecard method to measure Organizational Performance (LPD).

According to Kaplan and Norton (2000) Balanced Scorecard consists of 2 words Balanced which means balanced where employee performance is measured in a balanced way and Scoredcard which means score, from the actual performance results and is viewed with 2 aspects, namely short term and long term, financial and nonfinancial. The balanced scorecard consists of four perspectives, namely finance, customers, Internal Business Processes, Learning and Growth.

H1: organizational culture has a positive effect on organizational performance.

\section{Interaction of Management Competence in Moderating Cultural Relations Organization Against Organizational Performance}

Boyatzis (1982) defines competence as a human ability to behave by fulfilling job requirements within the parameters given by the organizational environment to achieve the desired results. Competence is knowledge of skills and abilities that are part of a person's self, so that a person can perform cognitive and effective behavior. Increasing managerial competence is very important in supporting work ability and determining the level of performance produced.

H2: management competence is able to strengthen the relationship of organizational culture to organizational performance.

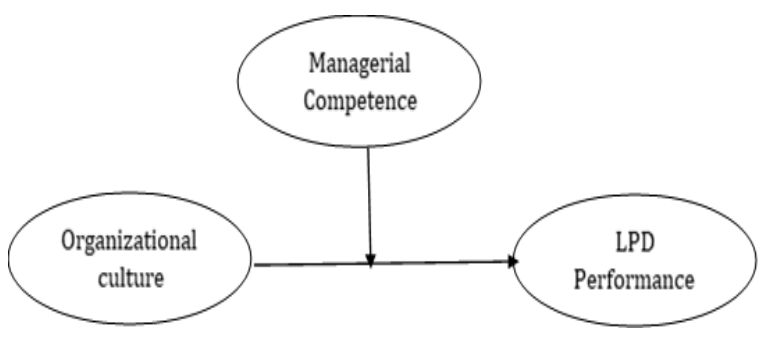

Figure.1 Research concept framework 


\section{MATERIALS \& METHODS}

The population of this study were all LPDs registered in Bali Province. We are only focus at Denpasar City and Badung Regency, amounting to 157 . The sampling method in this study used the saturated sampling method. Data was collected by distributing questionnaires to $157 \mathrm{LPD}$ in Denpasar City and Badung Regency. The construct in this research model as follows Tabel 2.
Table 1 Sampling Distribution

\begin{tabular}{|l|l|l|}
\hline No & Kecamatan & Jumlah LPD \\
\hline 1 & Denpasar Barat & 2 \\
\hline 2 & Denpasar Timur & 12 \\
\hline 3 & Denpasar Selatan & 11 \\
\hline 4 & Denpasar Utara & 10 \\
\hline 5. & Abiansemal & 34 \\
\hline 6 & Petang & 27 \\
\hline 7 & Mengwi & 38 \\
\hline 8 & Kuta Tengah dan Selatan & 28 \\
\hline Total & & 157 \\
\hline
\end{tabular}

Table 2 variable Measurement

\begin{tabular}{|l|l|l|l|}
\hline Construct & Definition & Item \\
\hline $\begin{array}{l}\text { Organizational } \\
\text { Culture }\end{array}$ & $\begin{array}{l}\text { As shared basic values (various } \\
\text { norms, ethics, beliefs and rules) that } \\
\text { are believed and implemented } \\
\text { consistently by each workforce }\end{array}$ & $\begin{array}{l}\text { 1) ensuring and carrying out LPD business ethics well, 2) } \\
\text { committed to serving with honesty in serving customers, 3) loyal } \\
\text { to LPD, 4) clearly separating LPD finances from finances for } \\
\text { personal and 5) provide a decent living for employees in running } \\
\text { their business. }\end{array}$ \\
\hline $\begin{array}{l}\text { LPD } \\
\text { Management }\end{array}$ & $\begin{array}{l}\text { The readiness of LPD managers in } \\
\text { facing competition to achieve goals } \\
\text { in accordance with the field of } \\
\text { business they are engaged in }\end{array}$ & $\begin{array}{l}\text { 1) educational background related to banking or economics to } \\
\text { promote and manage LPD, 2) a certain value system or honesty } \\
\text { to manage LPD, 3) management knowledge and its application to } \\
\text { support LPD management, 4) financial skills to support LPD } \\
\text { management }\end{array}$ \\
\hline $\begin{array}{l}\text { Organizational } \\
\text { Performance }\end{array}$ & $\begin{array}{l}\text { The work achieved by the LPD that } \\
\text { can guarantee the achievement of the } \\
\text { LPD's goals in developing the } \\
\text { business }\end{array}$ & $\begin{array}{l}\text { 1) the existence of their business is always maintained, 2) } \\
\text { efficiency in running the LPD, 3) the volume of their business } \\
\text { always increases from time to time, 4) LPD profits always } \\
\text { increase, and 5) LPD profits are invested in LPD progress }\end{array}$ & $\begin{array}{l}\text { Suparta } \\
\text { (2014) }\end{array}$ \\
\hline
\end{tabular}

The data analysis method used in this study is the structural equation model using the SmartPLS program. 3.0. Structural Equation Models (SEM) are statistical techniques that allow the simultaneous testing of a relatively complex series of relationships. A complete SEM model basically consists of a Measurement Model and a Structural Measurement Model aimed at confirming a dimension or factor based on its empirical indicators. Structural Model is a model regarding the structure of the relationship that forms or explains causality between factors. To create a complete model, the following steps need to be performed. 1) Development of theory-based models, 2) Development of path diagrams to show causality relationships, 3) Conversion of flowcharts into a series of structural equations and measurement model specifications, 4) Selection of the input matrix and estimation techniques for the built model, 5) Assess identification problems, 6) Model evaluation, 7) Interpretation and Modification of the model.

\section{RESULT}

\section{Characteristics of respondents}

The distribution of this research questionnaire began at the beginning of May 2021 until August 2021. The distribution was carried out using the services of a numerator who went directly to the sample where the LPD operated. There are 157 questionnaires distributed by researchers. From the distribution of the questionnaires that have been distributed, it can be seen that the results of the questionnaires that were returned and have been filled out completely according to the criteria were 157 questionnaires. Based on the results of the respondents' demographic answers, it can be explained that 1) the age characteristics of the respondents are dominated by the age of 41-50 years as many as 60 people or $38.22 \%$. 2) the characteristics of the respondent's education level are dominated by Diploma education levels as much as 57 or $36.13 \%, 3$ ) the gender characteristics of the respondents are dominated by males as many as 147 people or around $93.63 \%$. 
Ni Putu Rediatni Giri et.al. The role of management competency in moderating organizational cultural relations to LPD performance in Bali province.

\section{Measurement Model and Construct Validity}

Tabel 3. Measurement Model
\begin{tabular}{|l|l|l|l|l|}
\hline Variabel & Loading & $\boldsymbol{\alpha}$ & CR & AVE \\
\hline Organizational Culture & & 0,730 & 0,840 & 0,637 \\
\hline X1.2 & 0,808 & & & \\
\hline X1.3 & 0,774 & & & \\
\hline X1.4 & 0,812 & & & \\
\hline $\begin{array}{l}\text { LPD Management } \\
\text { Competence }\end{array}$ & & 0,706 & 0,810 & 0,519 \\
\hline M.1 & 0,702 & & & \\
\hline M.2 & 0,816 & & & \\
\hline M.3 & 0,712 & & & \\
\hline M.4 & 0,737 & & & \\
\hline LPD Performance & & 0,718 & 0,797 & 0,568 \\
\hline Y2 & 0,733 & & & \\
\hline Y3 & 0,804 & & & \\
\hline Y4 & 0,721 & & & \\
\hline
\end{tabular}

\begin{tabular}{|c|c|c|c|c|}
\hline Variabel & $\begin{array}{l}\text { Organiz } \\
\text { ational } \\
\text { Culture }\end{array}$ & $\begin{array}{l}\text { LPD } \\
\text { Manag } \\
\text { ement } \\
\text { Compet } \\
\text { ence }\end{array}$ & $\begin{array}{l}\text { Org*C } \\
\text { omp. }\end{array}$ & $\begin{array}{l}\text { LPD } \\
\text { Perfor } \\
\text { mance }\end{array}$ \\
\hline $\begin{array}{l}\text { Organizational } \\
\text { Culture }\end{array}$ & $(0,798)$ & & & \\
\hline $\begin{array}{l}\text { LPD Management } \\
\text { Competence }\end{array}$ & 0,670 & $(0,721)$ & & \\
\hline Org*Comp & 0,006 & 0,145 & $(1,000)$ & \\
\hline $\begin{array}{l}\text { LPD } \\
\text { Performance }\end{array}$ & 0,591 & 0,443 & 0,154 & $(0,754)$ \\
\hline
\end{tabular}

Notes. The diagonal value (in brackets) is the square root of the $A V E$, the value below the diagonal is the correlation between variables.

We perform various forms of testing related to the psychometric properties of the measurement model. The instrument used in this study was assessed from convergent validity, reliability and discriminant validity. First, confirmatory factor analysis (CFA) was performed for all latent variables in the structural model. The results of the CFA test in Table 3 show good convergent validity, this is indicated by all indicators having an outer loading above 0.70 and an AVE value of at least 0.50 as suggested (Hair et al., 2016). Second, the reliability of the measurement model (reliability) can be assessed from Cronbach alpha $(\alpha)$ and composite reliability (CR) exceeding the lower threshold of 0.70 as suggested by Hair et al., (2016). Thus, the variables in this study are considered quite reliable (Hair et al., 2016). Third, to test discriminant validity, we tested the value of the square root of the Average Variance Extracted (AVE). To meet good discriminant validity, the square root of the AVE for each variable must be higher than the correlation between that variable and other variables in the model (Fornell \& Larcker, 1981). The results of the discriminant validity test in Table 4 show that all of the above requirements have been met.

\section{Structural Model Testing}

Table 5 Path analysis and statistical testing
\begin{tabular}{|l|l|l|l|l|}
\hline & Coefficient & T Count & P Values & Information \\
\hline Organizational culture ->LPD Performance & 0.557 & 5,691 & 0.000 & Significant \\
\hline Managerial Competence ->LPD Performance & 0.049 & 0.482 & 0.630 & Not significant \\
\hline Org Culture**Comp->LPD Performance & 0.159 & 1,560 & 0.119 & Not significant \\
\hline
\end{tabular}

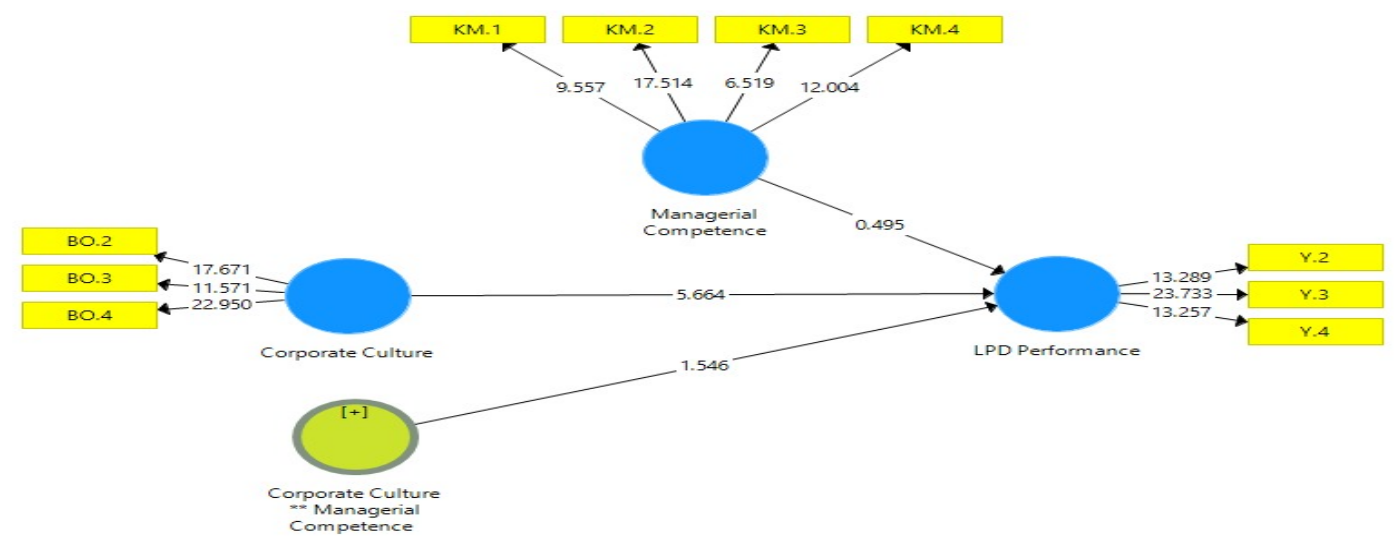

Figure 2 path coefficient test results

In PLS analysis, structural model testing is performed by testing the structural path and R2 scores of endogenous variables to assess the explanatory power of the 
structural model. The bootstrap procedure was carried out with 400 cases and 5,000 resampling used to test the significance of all pathways in the research model (Hair et al., 2016). The results of the structural model are shown in Figure 2. The results show that the model is able to explain $37.3 \%$ of the variation in LPD performance. Bootstrap results show that hypothesis 1 is supported. To support hypothesis 1, organizational culture has a significant positive effect on LPD performance $(\beta=$ $0.557, \mathrm{p}<0.000$ ). In contrast to hypothesis 2 , the interaction of organizational culture with management competence is not able to significantly improve LPD performance ( $\beta$ $=0.159, \mathrm{p}=0.119>0.05$ ).

\section{DISCUSSION}

Organizational culture has a positive effect of 0.557 on organizational performance and the relationship is significant at the 0.05 level with a t-statistic value of 5.691 which is greater than the ttable value of 1.96, it can be concluded that increasing variations in the role of organizational culture can significantly increase LPD performance so that hypothesis 1 is supported in this study. The support of hypothesis 1 (H1) has successfully confirmed the role of organizational culture theory that a strong organizational culture can increase company productivity and ultimately increase company performance. The results of this study support the results of previous studies from Koesmono (2005), Schein (2009), Adriaeni and Gustomo (2012) and Alharbi and Alyahya (2013).

The interaction of organizational culture with managerial competence has a positive effect of 0.159 on perceived usefulness and the relationship is not significant at the 0.05 level with a t-statistic value of 1.560 smaller than the t-table value of 1.96, it can be concluded that the increasing variation in the role of interaction organizational culture with managerial competence of LPD managers has not been able to significantly improve LPD performance so that hypothesis 2 is not supported in this study. This can be justified that the LPD in Bali has a special uniqueness in the selection of administrators, namely the consequence of the pararem or the result of the decision in the traditional village that the customary village chief or traditional prajuru automatically becomes the LPD administrator regardless of the competence of the traditional prajuru.

\section{CONCLUSION}

The results of this study prove empirically that LPD organizational performance is influenced by organizational culture but when organizational culture interacts with management competence, this relationship is not significantly able to improve organizational performance or in other words management competence is not a moderator of the relationship between organizational culture and LPD organizational performance. in Denpasar City and Badung Regency.

This study provides practical implications for the importance of organizational culture and competence in order to improve LPD organizational performance. Taking this into account, the results of this study can be used by the LPD supervisory apparatus to pay more attention to the competence of LPD management.

This study has several limitations, namely the research has a weak generalization aspect because it only applies in Denpasar City and Badung Regency. Further research can develop samples not only in Denpasar City and Badung Regency but also in all regencies or cities in Bali province considering Bali as a world tourist destination supported by strong customs based on the local wisdom economy, namely LPD, so the problems in LPD are not only occurred in the two districts alone. In addition, local wisdom variables can also be developed which can later be suspected as variables that affect the performance of LPD organizations such as Tri Hita Karana 
and leadership aspects of Asta Brata and Catur Purusa Artha.

\section{Acknowledgement: None}

\section{Conflict of Interest: None}

\section{Source of Funding: None}

\section{REFERENCES}

1. Anggiriawan, Putu Budi, Wirakusuma, Made Gede, 2015, Pengaruh Gaya Kepemimpinan Dan Budaya Organisasi Terhadap Kinerja Organisasi Dengan Penerapan Good Governance Sebagai Variabel Moderasi, E-Jurnal Akuntansi Universitas Udayana 10.2 (2015): 311-325

2. Ardiana, I.D.K.R, Brahmyanti, I.A dan Subaedi, 2010, Kompetensi SDM UKM dan Pengaruhnya Terhadap Kinerja UKM di Surabaya, Jurnal Manajemen Dan Kewirausahaan, Vol.12, No. 1, Maret 2010: 42-55

3. Alharbi, M. A. dan M. S. Alyahya. 2013. Impact of Organizational Culture on Employee Performance. International review of management and Business Research Journal2(1): 168-175.

4. Adriaeni , M. dan P. A. Gustomo. 2012. Analysis The Effect of Emotional Intelligence on Performance Through Leadership Style and Organizational Culture as A Moderator. Jurnal Manajemen dan Teknologi11(3): 250-268

5. Baba, Ali, 2014, Pengaruh Kompetensi, Komunikasi Dan Budaya Organisasi Terhadap Kinerjakaryawan Pt. Semen Bosowa Maros, Ekuitas: Jurnal Ekonomi dan Keuangan -Volume 18, Nomor 4, Desember 2014 :524-540.

6. Barney, Jay B. 2001. Is The Resource Based "View" A Useful Perspective For Startegic management Research? Yes. Academy of Management. The academy of Management review. Vol. 26. No. 1. Page: $41-56$

7. Callista, Natasha, 2016, Pengaruh Kompetensi Sdm Terhadap Kinerja Karyawan Pada Pt.Tresnamuda Sejati Cabang Surabaya, Jurnal AGORA Vol. 4, No. 2.

8. Davis, S. M.1985, Kerr, J. and Slocum, 2005 Managing corporate culture ,Cambridge,MA :Ballinger Pub.Co,1984.
9. Esra Akta, Cicekb, Mithat Kiyakc, 2011, The Effect Of Organizational Culture on Organizational Efficiency: The moderating Role Of organizational Environment and CEO Values.

10. Giberson, Tomas R. Giberson, Christian J. Resick, Marcus W. Dickson Jacqueline K. Mitchelson, Kenneth R. Randall dan Malissa A. Clark. 2009. Leadership and Organizational Culture: Linking CEO Characteristics to Cultural Values. Cultural Values. Journal of Business and Psychology. Volume 24: 123-137

11. Graham, J. R., Campbell, R. H., Poadak, J., \& Rajgopal, S. (2017). Corporate Culture: Evidence From The Field. Working Paper. Https://Doi.Org/10.3386/W23255

12. Hartono. (2016). Pedoman Survei Kuesioner, mengembangkan Kuesioner, Mengatasi Bias dan Meningkatkan Respon. Penerbit, BPFE - Yogyakarta. Edisi ke 2.

13. Hussein, N., Omar, S., Noordin, F., \& Ishak, N. A. (2016). Learning Organization Culture, Organizational Performance And Organizational Innovativeness In A Public Institution Of Higher Education In Malaysia: A Preliminary Study. Procedia Economics And Finance, 37, 512-519. Https://Doi.Org/10.1016/S22125671(16)30159-9

14. Ida Ayu Brahmasari, \& Agus Suprayetno. (2008). Pengaruh Motivasi Kerja, Kepemimpinan Dan Budaya Organisasi Terhadap Kepuasan Kerja Karyawan Serta Dampaknya Pada Kinerja Perusahaan (Studi Kasus Pada Pt. Pei Hai International Wiratama Indonesia). Jurnal Manajemen Dan Kewirausahaan, 10(1996), Pp.124-135. Https://Doi.Org/10.9744/Jmk.10.2.Pp. 124135

15. Kotter, J. P. and Heskett, J.L,1992, Corporate culture and Performance,New York The Free Press.

16. Kilmann, R.H ,1985 Corporate culture, managing the intangible style of corporate life may be the key to avoiding stagnation,Psychology Today

17. Koesmono, H. T. 2005. Pengaruh Budaya Organisasi Terhadap Motivasi dan Kepuasan Kerja serta kinerja Karyawan Pada Sub Sektor Industri Pengolahan Kayu Ekspor di Jawa timur. Disertasi. Universitas Airlangga,Surabaya.

18. Maabuat, Edward S, 2016, Pengaruh Kepemimpinan, Orientasi Kerja, Dan 
Ni Putu Rediatni Giri et.al. The role of management competency in moderating organizational cultural relations to LPD performance in Bali province.

Budaya Organisasi Terhadap Kinerja Pegawai (Studi Pada Dispenda Sulut Uptd Tondano, Jurnal Berkala Ilmiah Efisiensi, Volume 16 No. 01

19. Morgan, G. Images of organization.2nd ed.Thousand,Oaks:Sage Publication 1997

20. Ozzie, L., and Malelak, M.I (2015).Pengaruh Corporate Culture dan Organisational Commitment terhadap Financial Performance Perusahaan Keuangan di Surabaya.. Jurnal FINESTA, 3(1),p.79-84

21. Palan, R. 2007. Competency Management. Cetakan kedua. PPM.Jakarta Pusat

22. Putri, I. G. A. M. D. (2013). Pengaruh Budaya Organisasi Terhadap Kinerja Dalam Perspektif Balanced Scorecard. Jurnal Akuntansi Multiparadigma, 3(3), 462-470.

23. Schein, E. H. 2009. Culture: the missing concept in organization studies. Administrative Science Quarterly 41(2): 229-40.

24. Soedjono. (2005). Pengaruh Budaya Organisasi Terhadap Kinerja Organisasi Dan Kepuasan Kerja Karyawan Pada Terminal Penumpang Umum Di Terminal Surabaya. Jurnal Manajemen Dan Kewirausahaan, 7(1), Pp.22-47.

25. Solimun, Fernandes, A.A.R, \& Nurjannah. 2017. Metode StatistikGa Multivariat, Pemodelan Persamaan struktural (SEM) Pendekatan WarpPLS. UB Press.

26. Sulistyaningsih, A. 2009. Analisis Pengaruh Kepemimpinan, Kompetensi Karakteristik Individu, Locus Of Control Dan Penerapan Teknologi Informasi Terhadap Kinerja Pegawai Pada Dinas Pendidikan KabupatenKlaten.Excellent (1):1.

27. Schein,1992 E.H Organizational culture and leadership, 2nd edition, SanFrancisco, Jossey-Bass

28. Supartha, Wayan Gede, 2014, Peran Mediasi Budaya Organisasi Pada Pengaruh Kompetensi Dan Motivasi Ketua Lembaga
Perkreditan Desa (LPD) Terhadap Kinerja LPD (Studi Pada LPD Di Kabupaten Gianyar, Laporan Penelitian Program Doktoral Ilmu Manajemen Pascasarjana Universitas Udayana.

29. Sugiyono. 2014. Metode Penelitian Kuantitatif, Kualitatif, dan R\&D. Bandung: Penerbit Alfabeta

30. Wardani, R. K., Mukzam, M. D., \& Mayowan, Y. (2016). Pengaruh Budaya Organisasi Terhadap Kinerja Karyawan (Studi Pada Karyawan Pt Karya Indah Buana Surabaya). Jurnal Administrasi Bisnis (Jab), 31(1), 58-65.

31. Winarno, Alex dan Perdana, Yoga. 2015. "The Effecs of Competence and Motivation on Employee Performance at PT Pos Indonesia Bandung Cilaki Head Office”. Int'l Conference on Business, Marketing \& Information System Management. Prancis.

32. Yesil, S., \& Kaya, A. (2013). The Effect Of Organizational Culture On Firm Financial Performance: Evidence From A Developing Country. Procedia - Social And Behavioral Sciences, 81, 428-437. Https://Doi.Org/10.1016/J.Sbspro.2013.06.4 55

33. Yudistira, C. G. dan I. W. Siwantara. 2012. Pengaruh Gaya Kepemimpinan Transformasional Ketua Koperasi dan Kompetensi Kecerdasan Emosional Manajer Koperasi Terhadap Kepuasan Kerja dan Kinerja Manajer Koperasi di Kabupaten Buleleng. Jurnal manajemen, Strategi Bisnis dan Kewirausahaan6(1): $99-108$

How to cite this article: Giri NPR, Sudarmini K, Ganawati N. The role of management competency in moderating organizational cultural relations to LPD performance in Bali province. International Journal of Research and Review. 2021; 8(11): 163-170. DOI: https://doi. org/10.52403/ijrr.20211122 